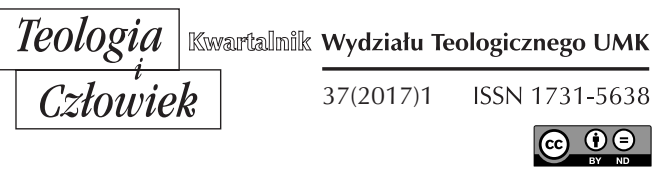

KS. MIROSŁAW MRÓZ*

TORUŃ

\title{
CZY GŁUPOTA JEST MORALNA? BRAKI W PROCESIE DOJRZEWANIA DO PEKNI MĄDROŚCI NA KANWIE NAUKI ŚW. TOMASZA Z AKWINU O LUDZKIM POZNANIU
}

DOI: http://dx.doi.org/10.12775/TiCz.2017.005

\section{WSPÓŁCZESNY KONTEKST LUDZKIEGO POZNANIA A LUDZKIE COGNITIVUM U ŚW. TOMASZA Z AKWINU}

Jak wiemy, kognitywistyka to dziedzina nauki, która aktualnie zajmuje się zjawiskami dotyczącymi działania umysłu, w tym także ich modelowaniem. Niektórzy używają zamiennie określenia: nauki kognitywne (ang. cognitive science) bądź nauki o poznaniu. Współcześnie kognitywistyka (cognitive science) jest dziedziną nauki interdyscyplinarnej, dążącą do unifikacji nauk szczegółowych, zajmujących się systemami poznawczymi. Bazuje na danych wywodzących się z psychologii, biologii, socjologii, historii itd. Można-śmiało powiedzieć, że w kontekście nauk kognitywnych nie ma już praktycznie miejsca dla samej filozofii. Co prawda, pozostał wąski zakres zagadnień, zwykle dotyczący tradycyjnego sporu, jaki toczył się przez wieki: relacja między duszą a ciałem. Zadaje

* Ks. Mirosław Mróz, prof. dr hab. nauk teologicznych w zakresie teologii moralnej, dr filozofii; pracuje w Katedrze Teologii Moralnej i Duchowości na Wydziale Teologicznym Uniwersytetu Mikołaja Kopernika w Toruniu (miroslaw.mroz@uni.torun.pl). 
się, że odpowiedzi dotyczące wspomnianej relacji orbitują jedynie wokół empirycznie poznawanych mechanizmów funkcjonowania mózgu i procesów fizjologicznych. Dzieje się tak, ponieważ szczegółowe pytania o naturę ludzkiego poznania oddano przede wszystkim przestrzeni psychologicznej. W refleksji tej brakuje jednak filozoficznych modeli działania rozumu, ujętych w pewien system całości, gdzie człowiek jawi się nie tylko jako wykrystalizowany i zamknięty czasowo w ciele duch, ale jako zasadnicza jedność pierwiastków duchowego i cielesnego, która jest rezultatem współdziałania różnego rodzaju przyczyn: zapewne materialnej i formalnej, ale także sprawczej i celowej. Tutaj jednakże wraz z przypisaniem człowiekowi struktury złożonej, rozstrzyga się problematyka antropologiczna związana z władzami człowieka. To właśnie Arystoteles - jako pierwszy - wskazał na podstawowe relacje istniejące $\mathrm{w}$ ukonstytuowanym bycie ludzkim ${ }^{1}$. Wyodrębnił on substancję i przypadłości, określił przedmiot działań duszy ludzkiej i władz, za pomocą których akty duszy są wykonywane. Pełnej systematyzacji władz i ich funkcji później dokonał św. Tomasz z Akwinu. Akwinata wskazał na podmiot duchowy, któremu przysługuje akt istnienia; tym podmiotem jest dusza ludzka, która - będąc jednocześnie formą substancjalną - konstytuowanemu przez siebie ciału udziela możliwości systemowych dla istnienia i funkcjonowania władz człowieka (potentiae animae).

Dotychczas uzyskane w kognitywistyce wyniki - w dużej mierze koncentrowały się na zrozumieniu sposobów poznania człowieka i działania osoby ludzkiej - w zależności od założeń przyjętych przez psychologię eksperymentalną, które chociaż wystrzegały się opierania na jakiejś wizji człowieka, poza naukową, co w tym wypadku oznacza doświadczalno-eksperymentalną. Neutralność w tym punkcie jest wyjściem racjonalnie apriorycznym. Współczesna psychologia - chcąc jakoby wystrzec się jakiegokolwiek uwikłania filozoficznego - sama wikła się w uprzedzające uprzywilejowanie racjonalistycznie potraktowanej bazy psychologii eksperymentalnej. Współczesna wiedza kognitywistyczna $\mathrm{z}$ jednej strony istotnie zmienia dotychczasowe spojrzenie na człowieka, $\mathrm{z}$ drugiej strony jednak sama wikła się w czysto jednostronne i racjonalistyczne użycie swoich wyników.

1 Por. J. Kalinowski, Arystotelesowska teoria sprawności intelektualnych, czyli o dwu pojęciach mądrości, „Roczniki Teologiczno-Kanoniczne” 5 (1955-1957) 4, s. 45-65. 
Propozycja realistycznego spojrzenia na człowieka daje miejsce także filozofii - i to tradycyjnie klasycznej, w której status ontyczny władz duszy, przede wszystkim ludzkiego poznania umysłowego, daje możliwość włączenia się do dyskusji kognitywistycznej. W ten sposób żadna opcja nie zostanie wyłączona ${ }^{2}$. Także ta, która przez wieki była uznawana za klasyczną, a mianowicie koncepcja ludzkiego poznania według myśli św. Tomasza z Akiwnu³.

Relacja pomiędzy filozofią racjonalną o człowieku i psychologią eksperymentalną można traktować uzupełniająco, uznając odmienny punkt wyjścia obu nauk. Rezultaty poznawcze nie mogą być tutaj sprzeczne, a wszystkie rozbieżności, które mogą się pojawić, dają możliwość weryfikacji metod zastosowanych przez te nauki oraz sprawdzenia ich wniosków. Św. Tomasz z Akwinu prezentuje swoją naukę o ludzkim poznaniu w obszarze nauki, którą dzisiaj ujmujemy jako filozofię człowieka, dokładniej psychologię racjonalną, gdzie temat duszy koncentruje się na naturze władz duszy (potentiae animae), zwłaszcza tych przynależących do władz poznawczych: ludzkiego cognitivum.

Można śmiało powiedzieć, że św. Tomasz z Akwinu jest filozofem ludzkiego poznania - w jego najszerzej rozumianej perspektywie ludzkiego umysłu: zarówno intelektu, jak i rozumu ${ }^{4}$. Kategorią zakresowo najszerszą w filozofii Akwinaty jest umysł, który obejmuje zarówno zagadnienie intelektu, rozumu, jak i woli. Używany tutaj przez Tomasza augustyński termin $m e n s^{5}$ jest właśnie odpowiednikiem dla władzy intelektu i woli. Człowiekowi przysługuje, według św. Tomasza, działanie umysłu, czyli

2 Por. S. Judycki, Umyst i synteza. Argument przeciwko naturalistycznym teoriom umystu, Lublin 1995, s. 23-59.

3 Por. M. Penczek, Wola i intelekt w filozofii Tomasza z Akwinu, Kraków 2012, s. $15-226$.

${ }^{4}$ Por. M. Mróz, Nowa lekcja mistrza Tomasza o mądrości. Refleksje na kanwie encykliki „Fides et ratio”, w: Polska filozofia wobec encykliki „Fides et ratio”, red. M. Grabowski, Toruń 1999, s. 153-171.

${ }^{5} \mathrm{~W}$ kognitywistyce termin umyst jest także przyjmowany jako szerszy niż intelekt czy rozum; obejmuje ogół aktywności mózgu ludzkiego, przede wszystkim takich, których posiadania człowiek jest świadomy oraz sam na nie się zdecydował. Prof. E. Żegleń używa terminu umysł (mens) „na oznaczenie całości stanów i procesów poznawczych jakiegoś individuum wraz z ich zawartością”, a także „system poznawczy” (por. E. Żegleń, Filozfia umystu, Toruń 2003, s. 26). 
duchowe, nieorganiczne i istotowo różniące się od osądu zmysłowego. Jest ono najwyższe $\mathrm{z}$ dostępnych - w porządku przyrodzonym - i obejmuje dziedzinę poznania umysłowego nazywaną intelektem (intellectus) oraz dziedzinę pożądania umysłowego (appetitus intellectivus), nazwaną krótko wolą (voluntas).

Akwinata dzieli władzę umysłowo-poznawczą na intelekt urzeczywistniony (intellectus in actu/intellectus agens) i intelekt możnościowy (intellectus in potentia). Ten ostatni posiada swoje podstawowe funkcje, takie jak: tworzenie pojęć ((pojęciowanie), czyli proste ujęcie rzeczy (simplex apprehensio), przeprowadzanie sądów twierdzących i przeczących, sądzenie (comprositio et divisio) oraz to, co nazywane jest rozumowaniem (ratiocinatio). Termin rozum (ratio) może odnosić się - w sensie węższym - do tej trzeciej, najważniejszej funkcji intelektu, jaką jest rozumowanie, bądź także, ze względu na nią - w znaczeniu szerszym - odnosić się do całej sfery poznania intelektualnego. Poznanie i pożądanie intelektualne wchodzą zaś w zakres duchowego poznania umysłowego.

Należy jednak zawsze pamiętać, że według Tomasza poznanie umysłowe nie jest dane jako gotowe: w postaci pojęć, sądów, czy wrodzonych rozumowań. Człowiek musi to wszystko dopiero wypracować, dojść do tego, co będzie stanowiło treść ludzkiego poznania umysłowego. Jest to orientacja arystotelesowska, w której poznanie zależne jest od zmysłów. Zmysłowe poznawcze władze zewnętrzne to: dotyk (tactus), smak (gustus), węch (olfactus), słuch (auditus), wzrok (visus), poznawcze władze wewnętrzne to: zmysł wspólny (sensus propprius/communis), pamięć bierna i czynna (memoria passiva et activa), wyobraźnia odtwórcza (imaginatio) i wytwórcza (phantasia) oraz władza osądu zmysłowego, która u człowieka - ze względu na bliskość poznania intelektualnego i wpływu na zmysły - nosi miano vis cogitativa, władza osądu myślowego (ratio particularis). Zmysłowe zaś władze pożądawcze (appetitus sensitivus) to uczucia (passiones), sfery popędliwej (irascibilitas) i pożądawczej (concupiscibilitas).

Całość ludzkiego compositum to dusza (anima) i ciało (corpus). Rolę zasadniczą w człowieku spełnia dusza jako forma ciała. Władze duszy, które różnicują się od substancji duszy realnie, a nie tylko myślnie, są jej przypadłościami (accidens). Człowiek, którego dusza jest najniższą 
$\mathrm{z}$ form samoistnych, posiada też intelekt najniższego rzędu, ale w pełni dostosowany do potrzeb naszej ludzkiej natury ${ }^{6}$.

Ważnym dla naszych późniejszych analiz jest stwierdzenie, że intelekt człowieka uczestniczy (participatio) w doskonałości wyższych od niego intelektów stworzonych (aniołów), a wraz z nimi w najwyższej pełni intelektu niestworzonego, czyli w Bogu. Ważność tego stwierdzenia ma swój walor nie tylko ze względu na swoją naturę teologiczną, wskazując na Boga jako na przyczynę istnienia i doskonałości wszystkich stworzeń (wszystko, co istnieje, uczestniczy ostatecznie w Bogu), ale także ze względu na fakt ogólnej zasady hierarchicznego ustopniowania - również różnych typów poznania na zasadzie uczestnictwa. Poznanie zmysłowe, jako niższe, uczestniczy w wyższym poznaniu intelektualnym, także ludzkie poznanie umysłowe uczestniczy w poznawaniu właściwym dla duchów czystych, ale ta partycypacja uwzględnia stan obniżony tej samej formy i ich hierarchię. Mamy tu do czynienia z uczestnictwem w poznawaniu o nierównej doskonałości. Człowiek nie posiada takich zdolności poznawczych jak anioł, który jest zdolny do intuicyjnego i do jakiegoś bezpośredniego oglądu dokonywanego przez sam intelekt (bez pomocy zmysłów). Odwrotnie niż w typie myślenia filozoficznego platońsko-augustyńskiego, u Arystotelesa i u św. Tomasza, w intelekcie człowieka nie ma niczego, czego przed tym nie było w zmysłach7. Tym samym, jak to już zostało wspomniane, całe działanie intelektualne, do którego zdolny jest człowiek, czerpie z materiału dostarczonego przez zmysły. Jest to zasadnicze stwierdzenie dla myśli zgodnej z tym, co twierdził Akwinata: nasz umysł, choć poznający, znajduje się na swoim własnym stopniu doskonałości; nie jest umysłem anielskim, ani zapewne boskim. Tylko ludzka pycha może przypisywać sobie takie prerogatywy, a także w konsekwencji traktować Boga jako jeden z bytów szczegółowych. Takie spojrzenie zupełnie przekreśla zrozumienie tego, kim jest Bóg sam w sobie, ukazując ludzką ignorancję. Intelekt jako formalna umysłowa władza poznawcza nie znajduje się zawsze w tym samym stopniu doskonałości, także u poszczególnych ludzi. U każdego człowieka intelekt - choć co

${ }^{6}$ Por. S. Swieżawski, Św. Tomasz na nowo odczytany, Poznań 1995, s. 45-79.

7 Por. S. Kowalczyk, Mądrość a wiedza w świetle wypowiedzi św. Augustyna, „Roczniki Filozoficzne KUL”, t. 15 (1967) 1, s. 111-118. 
do natury u wszystkich ludzie jednakowy - to jednak odmienny, inaczej „uporcjonowany”. Jak powie S. Swieżawski, „z racji rozmaitego przystosowania duszy do ciała". Zasada commensuratio animae ad hoc corpus została po mistrzowsku wyjaśniona w pracy Stanisława Swieżawskiego Centralne zagadnienie tomistycznej nauki o duszy ${ }^{8}$.

$\mathrm{U}$ Tomasza zatem istotną rolę odgrywa abstrakcja: proces wytwarzania pojęć z otrzymanych drogą zmysłową wrażeń. Całe umysłowe poznanie człowieka, od najniższych do najwyższych jego przejawów, jest przede wszystkim procesem abstrakcyjnym, wytwarzającym pojęcia. Nie można zapomnieć jednak i tego, że dla św. Tomasza ważne pozostaje także poznanie intuicyjne ${ }^{9}$, gdyż najgłębsze tajemnice człowiek poznaje tylko w nadprzyrodzonym świetle danym przez Boga. Akwinata ma jednak rację, że rzeczy posiadają swoją autonomiczną prawdę i mogą być badane same w sobie.

\section{TOMASZOWA POLEMIKA Z PLATONEM I AWERROESEM: "MIELIZNY" NA DRODZE LUDZKIEGO POZNANIA}

Dążenie do mądrości - ominięcie meandrów głupoty - jest sztuką życia; człowiek dla samego siebie staje się „artystą”. Jest kimś na wzór Michała Anioła, który - gdy pierwszy raz zobaczył i dotykał jakiegoś bloku marmuru - wiedział już, jaki posąg kryje w sobie owa skała. Człowiek winien poznać siebie i swoje możliwości umysłowe, aby wykorzystać własny potencjał, który jest darem niewyczerpanej miłości Bożej dla każdego. Oczywiście, nie można podejść do siebie w sposób despotyczny - narzędziem rygorów znawstwa - i przystąpić do obróbki swoich idealistycznych pomysłów na ukształtowanie własnych mocy poznawczych. Szybko można bowiem zostać „terrorystą” i wymuszać funkcjonalnie efektywny kształt własnego intelektu. Jakim artystą swojego intelektu powinienem być, aby nie stać się głupim, lecz mądrym? Jakie miejsce przyznać obróbce twórczej sztuki, zaangażowanej we własne formowanie umysłu? Czy mam wybrać

8 S. Swieżawski, Centralne zagadnienie tomistycznej nauki o duszy (Commensuratio animae ad hc corpus), „Przegląd Filozoficzny” 46 (1948) 1-3, s. 131-191.

9 Por. W. Daszkiewicz, Intuicja intelektualna w metafizyce, Lublin 2014. 
tylko zewnętrzne towarzyszenie i stymulowanie własnej pracy intelektu? Czy mogę zadziałać tak, aby zdobyć upragnioną mądrość? Jak podążać ku upragnionemu efektowi: zdefiniowanemu tutaj jako mądrość?

W pewnym sensie również św. Tomasz będzie zastanawiał się nad tą kwestią. Pozostawił on w wielu miejscach pewne ślady, które - odcztane razem - mogą dać pewną ciekawą całość. Ważne dla prześledzenia drogi poznania pozostają zapewne traktaty z Summa Theologiae „O darze mądrości” (II-II, q. 45) ${ }^{10}$ i „O głupocie” (II-II, q. 46) ${ }^{11}$, ale - z naszej perspektywy - na uwagę zasługuje przede wszystkim Quaestio undecima (q. 11, a. 1-4), De maestro, umieszczona w Quaestiones disputatae de veritate. Już w Pars Prima, kwestii 79 (De potentiis intellectivis) Akwinata będzie polemizował $\mathrm{z}$ dwoma typami błędnego podejścia do zrozumienia zagadnienia intelektu czynnego (intelectus agens) i intelektu możnościowego (intellectus possibilis), co uwypukli się w De maestro. Arystoteles, który zapłodnił pomysłowość komentatorów swojego dzieła De anima na temat intelektu czynnego, wypowiedział się w sposób budzący wiele pytań. Wśród starożytnych arystotelików żaden jednak nie postawił zagadnienia tak wyraźnie jak św. Tomasz z Akwinu, odpierając wszelkie błędy. Przed Tomaszem typowe były dwa stanowiska: pierwsze - Aleksandra z Afrodyzji - interpretującego kwestię o duszy w kontekście materialistycznym, i drugie: Temistjusza, parafrazującego dzieła Arystotelesa w krótkich i jasnych ujęciach. Był on wyrazicielem spirytualistycznej wersji arystotelizmu. Aleksander uważał, że intelekt możnościowy w nas jest śmiertelny, a intelekt czynny to istniejące poza ludźmi bóstwo. Temistjusz nie utożsamiał intelektu czynnego z bóstwem, ale uważał, że jest to jedno dla wszystkich, istniejące w umyśle duchowe światło (w jego spojrzeniu widać ogromny ładunek neoplatonizmu). Historia myśli filozoficznej będzie prowadziła do koncepcji filozofów arabskich i myślicieli wszelkich odcieni augustynizmu. Zgodnie z awerroizmem intelekty pojmować należy jako odrębnie bytujące - wspólne jednak dla całej ludzkości - duchowe substancje. Z kolei, w koncepcji

10 Tomasz z Akwinu, O darze mądrości (II-II, q. 45), w: Suma teologiczna, t. 16: Miłość (II-II, qq. 23-46), tłum. A. Głażewski, Londyn 1967.

11 Tomasz z Akwinu, O głupocie (q. 46), w: Suma teologiczna, t. 16: Miłość, tłum. A. Głażewski, Londyn 1967. 
platońsko-augustyńskiej nie istnieją różne od istoty duszy i realnie wzajemnie się różniące władze. Jeżeli więc czasami nawet będzie się mówiło o intelekcie czynnym, to nie w takim znaczeniu jak ujmuje to koncepcja arystotelesowsko-tomistyczna. $\mathrm{W}$ awerroizmie intelektu nie pojmuje się jako władzy, lecz utożsamia się go z istotą duszy. Św. Tomasz przyjmie swoistą via media, pomiędzy tymi skrajnymi podejściami, do teorii dwu intelektów. Tomasz stoi przy stanowisku Arystotelesa, że oba intelekty są „czymś w duszy”. Intelekt czynny nie jest jakimś bytem oderwanym od danego człowieka i jego duchowej duszy substancjalnej; podobnie jak intelekt możnościowy nie jest rozumiany jako czysty duch, bóstwo. Oba intelekty są w naszej duszy jako władze (potentiae animae). Dzięki intelektowi czynnemu posiadamy przyrodzone, duchowe światło poznania, dzięki czemu aktualizujemy to, co umysłowo poznawalne: przejście z wyobrażeń zmysłowych, uwikłanych w materialny kontekst, do ogólnego, duchowego pojęcia. Tutaj nasz intelekt spowinowaca się ze światem duchów czystych i światłem umysłu Bożego. Dzięki intelektowi możnościowemu człowiek jest zdolny do pojęciowego poznania umysłowego; do przejścia drogi: abstrakcji od materiału wyobrażeń zmysłowych, przez tworzenie pojęć i sądów, aż po rozumowanie. Ze sferą umysłowo-poznawczą związane są jeszcze inne struktury intelektualne, takie jak: umysłowa pamięć, rozum wyższy i niższy, inteligencja, intelekt spekulatywny i praktyczny. Według Akwinaty te struktury nie różnią się jednak od władz umysłowych, nie stanowią odrębnej władzy, ale utożsamiają się z przejawami intelektu, są bądź czynnościami, bądź sprawnościami intelektu.

Św. Tomasz uważa platońską propozycję za niestosowną, a nawet urągającą ludzkiemu rozumowi (absque ratione), gdyż Platon przyjmował, że prawdziwa wiedza preegzystuje w duszy człowieka od samego urodzenia. Człowiek posiada prawdy na własność, jako pochodzące z porządku wrodzonych idei, są one złożone w duszy ludzkiej. Pozostają one przed nim zakryte, ale powinny ujrzeć światło dzienne jak najprędzej, powinny wypłynąć i ukazać swoje światło - zostać w całej pełni przywrócone świadomości. Stąd cały proces procedowania na drodze edukacji, uzyskiwania mądrości, to swoista „anamneza”, przypominanie, gdzie wiedza preegzystująca od początku w duszy człowieka zostanie ponownie ujrzana i uchwycona. Człowiek zatem nie ma wpływu na kształt dochodzenia do prawdy. Jest to raczej proces natychmiastowej iluminacji, gdzie w sposób 
intuicyjny dostrzega się idee, stając się człowiekiem mądrym, jakby z natychmiastowym okrzykiem: „heureka!”, „znalazłem!”. Czy każdy z nas jest rzeczywiście Archimedesem? Tomasz zdaje się wskazywać drogę odmienną, właściwą każdemu ludzkiemu intelektowi: gdzie rzeczywisty wpływ na bycie mądrym zależny jest od pracy człowieka, a nie tylko okazjonalnego budzenia, przypominania, jakby zapalania zalegających pokładów prawdy i dobra, które już uprzednio zostały tam złożone. Akwinata nie uważa, że proces poznania prawdy: poprzez pojęciowanie, wydanie sądów rozumowych i samo rozumowanie to li tylko kwestia drugorzędna, gdzie zmysły uznawane są za przeszkodę $\mathrm{w}$ dotarciu do pokładów prawdy złożonych w duszy człowieka. Zmysłowości nie należy, według Tomasza, zwalczać, ale integrować. Zasadnicza jest zawsze komplementarność, a sfera cielesno-zmysłowa należy do podstawowych dóbr ludzkiej natury ${ }^{12}$.

Św. Tomasz z Akwinu odrzuca również koncepcję awerroistyczną, która - z kolei -zatraca wątek indywidualności osoby ludzkiej. Awerroes sądził, że jednostkowy intelekt nie ma racji przetrwania. Trwa jedynie duch całej ludzkości i to ludzkość jest tą, która jest priorytetowa wobec konkretnego człowieka. Jednostka posiadałaby jedynie „bierną dyspozycyjność", a wszystko, co poznaje należy nie tyle do niej, co do wszystkich. Wiedza indywidualna powinna być więc relatywizowana, człowiek nie powinien posiadać swoich partykularnych wyobrażeń i przedstawień. Trzeba zatem podjąć się zadania zatracenia tego, co indywidualne i jednostkowe, a wyakcentować ogólną jedność, ogólny sens, przez który zdobywa się prawdziwe rozeznanie i upragnioną mądrość. Należy usprawnić jedynie proces jednoczenia się ze wspólną myślą wszystkich, aby w ten sposób uzyskać wyższą świadomość ludzką. Tak zaprezentowana koncepcja awerroistyczna, przez nas dodatkowo w tym miejscu wyostrzona, nie mogła znaleźć akceptacji Akwinaty, który podkreślał godność osoby ludzkiej w jej indywidualnej racjonalności. Wspomniana koncepcja zaprzecza wolności osoby ludzkiej, możliwości indywidualnego rozwoju, poprzez oczywistą formę determinizmu, a w konsekwencji proponuje odpowiedzialnością zbiorową, w której nie jest się odpowiedzialnym za brak mądrości, za swoją głupotę, za swoje głupie czyny.

12 Por. M. Mróz, Miejsce nauczyciela $w$ procesie edukacji ucznia $w$ świetle traktatu „De magistro” św. Tomasza z Akwinu, „Paedagogia Christiana” 1 (1997), s. 101-120. 
Jaka jest wizja drogi mądrościowego procesu poznawczego, który stoi u podstaw ludzkiej odpowiedzialności za siebie, drugich i świat? Człowiek z konieczności winien poznać strukturę zdobywania wiedzy i prawdy. Tomasz odnajduje w ludzkiej duszy naturalne usposobienie obejmujące pewną drogę - i proces ludzkiego poznania, w którym zasady płodności rozumu ludzkiego można poznać i je usprawnić. Potrzeba jest praca własna, praca zmysłów i umysłu, najlepiej wsparta pouczeniem dobrego mistrza. Wzrastanie w mądrości to sztuka, przechodzenie z możności wiedzy w stan urzeczywistnienia, z niewiedzy do wiedzy. Św. Tomasz sztukę tę porównuje do sztuki medycznej. Człowiek, tak jak lekarz, ma do czynienia z żywą istotą: z żywym organizmem natury. Sztuka lekarska jest najskuteczniejsza, kiedy lekarz ma na uwadze własne reguły przynależne naturze leczonej osoby. Trzeba podążać tropem samoregenerującej się natury. Podobnie i w wychowaniu i edukacji trzeba zadbać o to, aby poznawszy swoje konkretnie indywidualne możliwości poznawcze, wybrać tę drogę wzrostu ku mądrości, która będzie zgodna ze strukturą i formą „organizmu” przejmującego podmiotu, jakby leczonego z niewiedzy.

$\mathrm{W}$ procesie kształcenia poznaje się najpierw strukturę aktywności umysłowej, aby idąc drogami natury, przedsięwziąć intelektualne i duchowe kierownictwo nad właściwym procesem twórczym. Bezsprzecznie winno się również aplikować „środki lecznicze”, w których posługa mistrza staje się nieodzowna. To on winien wzmocnić umysł prowadzonego ucznia, opierając się na własnym doświadczeniu. Niemniej jego rola jest służebna, gdyż on jedynie pomaga, jest czynnikiem zewnętrznym, narzędziem wobec własnych sił każdego człowieka pojętego indywidualnie. Via activa procesu wzrastania $\mathrm{w}$ mądrości to towarzyszenie, stymulowanie, rozszerzanie drogi przez uaktywnianie poszczególnych elementów struktury intelektu.

\section{NIEZBYWALNOŚĆ CNÓT INTELEKTUALNYCH NA DRODZE KU PEŁNI MĄDROŚCl}

Człowiek, pragnący dojść do mądrości, winien mieć na względzie moc natury, ale także możliwość jej usprawnienia. Człowiek bowiem nie jest bytem statycznym, ale dynamicznym - mającym możliwość rozwoju 
i urzeczywistnia swojej naturalnej potencjalności. Dla Tomasza ważne są władze poznawcze duszy, ale także sprawność tych władz oraz współdziałanie sfery umysłowej z pożądawczą, z wolą i z uczuciami. Jeżeli Tomasz używa Augustyńskiego terminu mens, to właśnie dlatego, aby oznaczyć nim łącznie całą sferę umysłową. Ważną rolę we właściwym posługiwaniu się władzami umysłowo-poznawczymi odgrywają sprawności (habitus). Sprawności dodatnie, czyli cnoty, przysługują duchowym władzom umysłowym. W odniesieniu do władz zmysłowych można tylko mówić o usprawnieniach „mechanicznych”. W tym wypadku jednak, tzn. w stosunku do intelektu i woli, można mówić o „pełnych” sprawnościach: cnotach jako dyspozycjach dodatnich, wadach zaś jako dyspozycjach ujemnych. Działania duszy nie są odseparowane i mają na siebie wpływ (mniejszy lub większy). Tomasz wymienia całą gamę cnót, które przynależą do sfery poznawczej, w której mamy do czynienia z trzema cnotami przewodzącymi ludzkiemu życiu spekulatywnemu. Są to: intellectus principiorum, czyli pojętność - sprawność, która pozwala poznać pierwsze zasady teoretyczne; scientia, czyli wiedza, która usprawnia w wyciąganiu z tych pierwszych zasad wniosków, dających obraz rzeczywistości, oraz sapientia - mądrość, dzięki której człowiek może wyciągnąć wnioski najgłębsze i ostateczne, sięgające dalej niż poznanie rzeczywistości naturalnej ${ }^{13}$. W sferze pożądawczej mamy do czynienia $\mathrm{z}$ cnotami moralnymi: z racjonalną roztropnością (prudentia), której przypada zadanie nad wyraz specyficzne, albowiem swoją pracę roztropność wykonuje zarówno w zakresie działa prawidłowej spekulacji, jak i praktyki; sprawiedliwością (iustitia), której podmiotem działania jest wola; męstwem (fortitudo), w którym obszarem docelowym jest usprawnienie uczuć popędliwych (irascibilitas) i z umiarkowaniem (temperantia), działającym w przestrzeni uczuć pożądawczych (concupiscibilitas). Można tutaj nadmienić, że w dziedzinie intelektu praktycznego cnotą kierującą wytwarzaniem (facere) jest „sztuka” (ars), zaś postępowaniem (agere), kieruje cnota znajomości pierwszych zasad postępowania praktycznego: prasumienie (synderesis), aktualizowana przez sumienie (coscientia). Trzeba w tym miejscu nadmienić cnoty teologalne: wiarę (fides), gdzie podmiotem jest

13 Tomasz z Akwinu, O cnotach umysłowych (q. 57), w: Suma teologiczna, t. 11: Sprawności (I-II, q. 49-70), Londyn 1965. 
ludzka ratio, nadzieję (spes), odnoszącą się do woli, ale także do uczuć, oraz cnotę miłości (caritas), która także działając w obszarze ludzkiej woli, daje pełną formę urzeczywistnienia i jedność całokształtu ludzkich usprawnień. Przestrzeń poznania intuicyjnego zagospodarowują przede wszystkim dary Ducha Świętego: dar pojętności (donum intellecti), dar umiejętności (donum scientiae), dar mądrości (donum sapientiae), dar rady (donum consilii), a więc te, które wspomagają swoją mocą przestrzeń czynności ludzkiego intelektu oraz dar pobożności (donum pietatis), dar bojaźni Bożej (domum timoris) oraz dar męstwa (donum fortitudinis), które wspomagają obszar działań woli, chociaż dwa ostatnie tutaj wymienione swoim wpływem sięgają również w przestrzeni ludzkich emocji.

Bezsprzecznie dla Akwinaty wszystkie cnoty intelektualne, także te moralne, jak również przestrzeń dynamizmu cnót teologalnych, należy do sposobu realizacji autentycznego ludzkiego poznania: są droga ku mądrości. Ludzki rozum w niektórych sprawach podlega wpływowi woli i uczuć, i tu właśnie potrzeba cnót moralnych, które gwarantują mu spełnienie właściwej roli w kontekście integracji władz duszy, jak i jedności duszy i ciała. Cnoty nie są tu jakimś jarzmem narzuconym naturze, aby ją dyscyplinować wbrew niej samej, ale są dodatkowym doskonaleniem w nurcie jej rzeczywistego spełnienia. Zharmonizowanie poziomu intelektualnego i wolitywnego okazuje się zadaniem niezmiernej wagi, także dla samego ratio. Cnoty moralne nie można ujmować jako łagodnego jarzma dla utrzymania panowania rozumu, podobne także sprawnie działający - pod wpływem cnót intelektualnych rozum - nie może być pojmowany jako suwerenny przedmiot. Tomaszowa droga ludzkiego poznania unaocznia potrzebę współpracy wszystkich cnót, gdzie dojrzałość intelektualna człowieka jednoczy cnotę miłości z mądrością. To właśnie w rozdźwięku pomiędzy kształtowaniem cnót intelektualnych i moralnych leży często wielki dramat człowieka. Ma on wiele przyczyn. Jednym z nich był przesadny racjonalizm doby oświecenia, innym razem w epoce romantyzmu jednostronny emocjonalizm. U Tomasza, intelekt usprawniony własnymi cnotami spekulatywnymi nie lęka się cnót moralnych, tym bardziej także cnót teologalnych i intuicyjnego poznania płynącego z darów łaski Bożej. Odwaga rozumu $\mathrm{w}$ poszukiwaniu prawdy łączy się zawsze u Akiwnaty z odwagą odnajdywania autentycznego dobra. Człowiek jest zdolny do wypracowania sobie jednolitej i organicznej koncepcji poznania, które 
„oddycha” jednością, gdzie wymiar sapiencjalny ostatecznie polega na poszukiwaniu całościowego sensu ludzkiej egzystencji.

\section{W POSZUKIWANIU LEKARSTWA NA GKUPOTĘ I BRAKI MYŚLENIA SAPIENCJALNEGO}

Cnotą usprawniającą rozumowanie (ratiocinatio) intelektu jest dla Akwinaty mądrość. To mądrość jawi się jako wyższa sprawność poznawcza, uświadamiająca człowiekowi nie czynniki odrębne, ale wspólne wszystkim rzeczom, a jednocześnie głębsze i wyższe. Człowiek obejmuje już całość rzeczywistości: zna nie to, co jednostkowe, ale to, co powszechne, a tym samym cnota mądrości pokonuje wszelkie trudności w poznaniu najgłębszych korzeni rzeczywistości. Jednak ta koncepcja, tzn. mądrości jako poznania i działania skierowanego ku temu, co powszechne, daje podstawy do jasnego rozróżnienia mądrości cząstkowej. Św. Tomasz, idąc za Arystotelesem, powie wprost: „Jak twierdzi Filozof, zadaniem mądrego jest myśleć o przyczynie najwyższej, według której z całą pewnością osądza się wszystko, i stosownie do której wszystko należy porządkować. Zaś przyczyna najwyższa może być rozumiana dwojako: albo bezwzględnie, albo w pewnej dziedzinie. Kto zna przyczynę najwyższą w danej dziedzinie i nią potrafi osądzać i porządkować wszystko, co do tej dziedziny należy, jest mądrym w tej danej dziedzinie, np. w medycynie lub architekturze"14. Mądrość, płynąca z zaszyfrowania świata, nie ma jednak mocy ostatecznej: ukierunkowania życia; mądrości sprawiającej współnaturalność (connaturalitas) człowieka z Bogiem przez otrzymaną łaskę. W ten sposób Tomasz wprowadzi nową kategorię, która - przyjęta w swojej pełni - będzie stanowiła skuteczną drogę dojścia do mądrości ${ }^{15}$.

Tak zarysowana mądrość daje nam zrozumienie głupoty, którą św. Tomasz omawia w Secunda Secundae, kwestii 46. Mądrość, dochodząca do poznania tego, co uniwersalne zostaje zanegowana przez głupotę, w sposób ukazujący pełen tragizm zamknięcia się człowieka w przestrzeni tego, co partykularne. Nie jest to jednak li tylko proste zatrzymanie się

\footnotetext{
${ }^{14}$ S. Th., II-II, q. 45, a. 1c.

15 Por. tamże.
} 
na rzeczach tego świata i ich namacalnej konkretności, chociaż i ono ma tu miejsce, ale także potraktowanie samej Prawdy, Boga, jako martwego przedmiotu. Jako że człowiek nie jest w stanie wyprzeć Prawdy Żywej ze swojego serca, ponieważ jest capax Dei, głupota jest próbą posiadania Boga jako przedmiotu. Nieobecność, która w świecie ukazując swoją chwałę daruje siebie, ale którą można posiąść, ufaktycznić.

Tomasz nawiąże do twierdzenia św. Izydora z Sewilii, który w swoich Etymologiach ${ }^{16}$ termin stultitia (głupota) wyprowadza od stupor, czyli odrętwienie, paraliż; wszakże, to przede wszystkim luxuria (rozwiązłość) blokuje dostrzeżenie promieniującej na świat mądrości Bożej. To luxuria kieruje utrzymaniem człowieka w przestrzeni tego, co ziemskie. Samo pojęcie tej wady wywodzi się od lux, „światło”, które w tym wypadku jest wadliwe i w sobie samym stanowi brak jasności i przejrzystości. Człowiek nie dostrzega chwały Bożej w rzeczach, a przez tkwienie w braku światła dostaje na nie wręcz uczulenia, obrzydzenia. Oczy nie chcą widzieć blasku mądrości Bożej. To, co człowiek spostrzega winien odnosić do Boga. Zatrzymanie się na samych przedmiotach, bez spostrzegania Bożego splendoru obecnego w rzeczach jest już samo przez się głupotą. Akwinata jednak, chociaż metafora głupoty jako tkwienia w ciemności jest mu bliska, to - pod wpływem wspomnianego już tutaj Izydora z Sewilii - zostanie ona porównana do „utraty smaku”. „Człowiek bowiem mądry [...] «nazywany jest takim od smaku, bo jak zmysł smaku jest zdolny rozróżnić smak potraw, tak mądry wyczuwa różnicę w rzeczach i przyczynach»"17. Do głupoty wiedzie droga odwrotna niż do ruchów intelektu. Kolejne kroki dojścia do głupoty, do utraty smaku wiedzie przez tępotę umysłu (hebetudo) i ignorancję (ignorantia). Człowiek głupi to zatem nie tylko taki, który ma jakieś defekty inteligencji, ale który nie potrafi „czytać” rzeczy świata, i wydawać o nich właściwych sądów. Głupi ma jeszcze, co prawda, zmysł sądzenia, gdyż przynależy on naturze jego intelektu, ,ale w stanie osłabionym (habet, sed hebetatum), gdy $\mathrm{u}$ mądrego zmysł ten jest delikatny i wyostrzony ${ }^{18}$. To jakby pierwsza faza działania głupoty, najpierw stan osłabienia zmysłu pojmowania i sądzenia,

\footnotetext{
16 Izydor z Sewilli, Etymologiarum, lib. X, ad litt. S (PL 82, 393).

17 Por. tamże.

${ }_{18}$ S. Th., II-II, q. 46, a. 1c.
} 
aż po całkowity paraliż. Przez głupotę człowiek pozostaje na poziomie zmysłów: „nie smakują [mu nawet] rzeczy słodkie, bo jego zmysł smaku doznał zepsucia"19. Otumanione zmysły mogą dojść aż do całkowitego odrętwienia, pozbawiającego człowieka zmysłu duchowego. Dla niego nie istnieje nic poza faktami, nie ma żadnej prawdy, której w rzeczach należy poszukiwać, a kto o nią pyta, staje się śmieszny; istnieje tylko ten świat i nic więcej, i z niego to trzeba korzystać, zdobywając jak najwięcej przyjemności zmysłowej w jak najkrótszym czasie i tak intensywnie, jak to jest tylko możliwe. Wszystko dzieje się stopniowo, ale konsekwentnie. Zło, które jest tu brakiem właściwego smaku, drąży intelekt coraz bardziej, wikłając go w ciemnotę poznania, która jest przede wszystkim ciemnotą w spojrzeniu na światło Boże.

Myślenie ma to do siebie, że zaczyna się w rozumie, ale na rozumie się nie kończy, bowiem oplata całą duszę, wszystkie sektory władz duszy, jej twórcze moce, wszystkie je potentiae animae. Myśl zapoczątkowuje działanie, za które człowiek ponosi odpowiedzialność. Braki w poznaniu powstają, gdyż rozum ludzki ogranicza, bądź wręcz zaprzecza swojej funkcji kierowniczej i jednoczącej dla całości szerokiego kompleksu wewnętrznych czynności duszy. Głupota dla Tomasza nie ma tyle wspólnego $\mathrm{z}$ niedostatkiem inteligencji czy nawet $\mathrm{z}$ umysłowym niedorozwojem, co właśnie z brakiem wewnętrznego scalenia, a przez to z zamknięciem się na ostateczny, sapiencjalny wymiar ludzkiego poznania. Człowiek zatracił swoje rectitudo, prawe ukierunkowanie, które zostało $\mathrm{w}$ pewnym sensie niejako przerwane, bądź zasklepione, i to najczęściej na poziomie jedynie czystej faktyczności, podczas gdy „ciąg” procesu myślowego winien przejść wszystkie obszary duszy, docierając aż do najdalszych jej pokładów. Dążyć od tego, co spekulatywne, od rozumu wiedzącego (scientificum) do rozumu obmyślającego (ratiocinativum), aż po poznanie zmysłowe (sensitivum), które obejmuje swoim zasięgiem również to, co w duszy przynależy do sfery pożądawczej, wraz z czynnościami wegetatywnymi i ruchowymi. Ostatecznie umacniać jedność duszy i ciała.

Głupota nie psuje zatem samego rozumu, gdyż może on dalej wykazać się bystrością, określaną przez Akwinatę terminem industria, czy też biegłością rozpoznawania konkretu, będącą z kolei odpowied-

19 S. Th., I-II, q. 46, a. 2 c. 
nikiem Tomaszowej ingeniositas. Rozum faktyczny (ratio particularis) osiąga wymierne owoce swojej działalności, co pokazują liczne zdobycze techniczne i nauki eksperymentalne. Bywa on jednak fatalny w swoich skutkach, na polu odpowiedzialności za człowieka jako takiego, za drugich i świat. Rozum niweczy swoje dobro (corruptio), uszczupla je (diminutio) oraz obniża swoje całościowe oddziaływanie (remissio), a przez co staje się jednostronny, i jaśnieje jedynie blaskiem rozpoznania faktycznego i technicznego, przy czym zatraca ową jasność mądrościową, jasność całości. Wewnętrzny przebieg „procesu myślowego” we wnętrzu samej duszy, który posiadając konsekwencje dla ludzkiej odpowiedzialności za czyny, osądza je jako złe. Widać to z całą ostrością w opisie prawidłowego procesu dojrzewania do ludzkiej mądrości, rozumianej i tutaj wspólnie jako mądrość teoretyczna (speculativa) i mądrość praktyczna (practica). Rozumowi przysługuje mądrość serca, woli przysługuje zaś miłość mądrości. Tylko człowiek w pełni dojrzały i zintegrowany cieszy się Prawdą i Dobrem, raduje się obecnością poznanego i ukochanego Boga.

Streszczenie. Podczas gdy niektórzy kognitywiści podważają charakter moralny ludzkiego postępowania oraz wskazują na jego deterministyczną zależność od czynników pracy mózgu, trzeba nam na nowo pytać się o etyczność procesu poznawczego. Czy takie pytanie w ogóle jest uprawnione? Często w naukach kognitywnych nie ma już miejsca na etykę i zagadnienia natury moralnej. Św. Tomasz z Akwinu widział człowieka jednak zawsze całościowo: duszę i ciało, jego wiarę i rozum, cnoty intelektualne w łączności z cnotami moralnymi i teologalnymi. Artykuł, wprowadzając kwestię dotyczącą możliwości etycznej odpowiedzialności za głupotę, pragnie wskazać na niektóre zagadnienia etyczne w kontekście budowania procesu poznawczego. Głupota nie jest zatem tylko brakiem inteligencji lub niedorozwoju umysłowego, ale raczej wiąże się z brakiem wewnętrznej spójności władz duszy oraz integracji czynników formujących poszczególne etapy wiedzy. Prawdziwa mądrość jest zawsze mądrością serca.

Słowa kluczowe: poznanie ludzkie; wiedza; cnoty intelektualne; mądrość; głupota; Tomasz z Akwinu.

Abstract. Is stupidity moral? Deficiencies in the process of maturation into wisdom on the canvas learning St. Thomas Aquinas of human cognition. While the braver cognitivists try to subject the nature of morality and its formalisation within the frames of ethical theories to reinterpretation, we need to think whether cognitive science is able to make such changes. Surely, ethics shaped upon an appropriate vision of human nature should also take into consideration information about the knowledge of reality 
and truth. Saint Thomas Aquinas is considered one of those significant theorists and practitioners of morality who analysed in depth the principles of how judgements about wisdom and morality are formed. Are the teachings of Thomas Aquinas today merely an unnecessary "spirit of the past"? They are not and his analysis of the principles of cognition even nowadays can inspire further studies on human choices and subjective ethical actions. The reason is entitled to wisdom, not folly, and the soul is entitled to perfection, not numbness.

Keywords: human cognition; knowledge; intellectual virtues; wisdom; stupidity; Thomas Aquinas.

\section{BIBLIOGRAFIA}

Arystoteles, Etyka nikomachejska, Etyka wielka, Etyka eudemejska, O cnotach $i$ wadach, w: Dzieła wszystkie, t. 5, Wydawnictwo Naukowe PWN, Warszawa 1996.

Benedykt XVI, Wolni od pychy intelektualnej dążymy do prawdziwej Mądrości (Przemówienie do wykładowców i studentów rzymskich uczelni kościelnych), L'Osservatore Romano, 30 (2009) 1/309, s. 38-39.

Jan Paweł II, Dar Mądrości, L’Osservatore Romano, 10 (1989) 4/112, s. 8.

Judycki S., Umyst i synteza. Argument przeciwko naturalistycznym teoriom umysłu, Lublin 1995.

Kalinowski J., Arystotelesowska teoria sprawności intelektualnych, czyli o dwu pojęciach mądrości, „Roczniki Teologiczno-Kanoniczne” 5 (1955-1957) 4, s. 45-65.

Mazur P.S., Imiona intelektu, KUL, Lublin 2004.

Mróz M., Teologiczne podłoże odzyskiwania wartości, „Ateneum Kapłańskie” 129 (1997), 2-3 (531-532), s. 163-174.

Mróz M., Nowa lekcja mistrza Tomasza o mądrości. Refleksje na kanwie encykliki „Fides et ratio”, w: Polska filozofia wobec encykliki „Fides et ratio”, red. M. Grabowski, Toruń 1999, s. 153-171.

Mróz M., Miejsce nauczyciela w procesie edukacji ucznia w świetle traktatu „De magistro” św. Tomasza z Akwinu, „Paedagogia Christiana” 1 (1997), s. 101-120.

Mróz M., Człowiek w dynamizmie cnoty, Toruń 2001.

Penczek M., Wola $i$ intelekt w filozofii Tomasza z Akwinu, Kraków 2012.

Salij J., Mądrość i głupota, w: Eseje tomistyczne, Poznań 1998, s. 40-51.

Swieżawski S., Św. Tomasz na nowo odczytany, Poznań 1995.

Swieżawski S., Centralne zagadnienie tomistycznej nauki o duszy (Commensuratio animae ad hc corpus), „Przegląd Filozoficzny” 46 (1948) 1-3, s. 131-191.

Tomasz z Akwinu, O cnotach rozumu. Komentarz do VI księgi Etyki nikomachejskiej Arystotelesa, tłum. M. Głowala, J. Kostaś, M. Otlewska, w: Ziółkowski, Wrocław 2010.

Tomasz z Akwinu, O darze mądrości (II-II, q. 45), w: Suma teologiczna, t. 16: Miłość (II-II, qq. 23-46), tłum. A. Głażewski, Londyn 1967. 
Tomasz z Akwinu, O głupocie (q. 46), w: Suma teologiczna, t. 16: Miłość, tłum. A. Głażewski, Londyn 1967.

Tomasz z Akwinu, O cnotach umystowych (q. 57), w: Suma teologiczna, t. 11: Sprawności (I-II, q. 49-70), Londyn 1965.

S. Thomae de Aquino, Summa Theologiae, Cinisello Balsamo (Milano) 1988.

Żegleń U., Filozofia umysłu: dyskusja z naturalistycznymi koncepcjami umysłu, Toruń 2003. 